\title{
BRINGING THE NEW PHILOLOGY TO PACIFIC LEGAL HISTORY
}

\author{
R P Boast *
}

This article is a study of the main features of the so-called new philology, a school of historians based mainly in the United States who have pioneered a novel approach to the history of indigenous societies under colonial rule by focusing on day-to-day "mundane" texts, typically legal documents or documents preserved in legal records, written in indigenous languages. It is suggested that New Zealand provides a unique opportunity to experiment with the approaches of the new philology outside Latin America as it meets the basic requirement of having preserved a significant amount of written documentation recorded in an indigenous language. What such a study might reveal is unclear, but the overall conclusion is that it should certainly be attempted. One weakness of the new philology, however, is that while it is based strongly on legal documents, it does not engage with law or with legal processes as such.

\section{INTRODUCTION}

What is legal history? More narrowly, how should the legal history of the 19th century colonial encounter in the Pacific ${ }^{1}$ be approached? To date, the legal history of the colonial encounter in the Pacific, for example in New Zealand, Hawai'i and Australia, has on the whole been a variant of fatal impact history. Fatal impact history is one of those sometimes misleading but nevertheless useful catch-all phrases that usefully conveys a particular approach and style. Taking its name from a popular book by Alan Moorehead, ${ }^{2}$ this approach to Pacific history has, however, perhaps never been better epitomised than by Evelyn Waugh in Brideshead Revisited, where the tragic figure of Sebastian is likened to "a Polynesian": 3

* Professor of Law, Victoria University of Wellington; Barrister.

1 Mostly this article will focus specifically on the literature relating to the history of the Māori people in 19th century New Zealand, as an example of trends and developments in Pacific history. I admit to being less familiar with the historiographies of, for example, 19th century Hawai'i or Tahiti.

2 Alan Moorehead The Fatal Impact: An Account of the Invasion of the South Pacific 1767-1840 (Harper and Row, London, 1966).

3 Evelyn Waugh Brideshead Revisited (Penguin Books, London, 2009) at 123. 
By the blue waters and rustling palms of his own mind he was happy and harmless as a Polynesian; only when the big ship dropped anchor beyond the coral reef, and the cutter beached in the lagoon, and, up the slope that had never known the print of a boot, there trod the grim invasion of trader, administrator, missionary, and tourist - only then was it time to disinter the archaic weapons of the tribe and sound the drums in the hills; or, more easily, to turn from the sunlit door and lie alone in the darkness, where the impotent, painted deities paraded the walls in vain, and cough his heart out among the rum bottles.

Since the 1950s, as is well-known, there has been a strong reaction away from fatal impact history. In Pacific history the reaction is associated especially with J W Davidson (a New Zealander), who became Professor of Pacific History at the Australian National University in 1951 and who published his history of the Samoan independence movement, Samoa mo Samoa, in $1967 .{ }^{4}$ Today historians rightly emphasise continued Polynesian resilience and cultural vitality. ${ }^{5}$ Nicholas Thomas has written that although "Polynesian cultures had been buffeted by disease and had lost their political autonomy", the "suggestion that indigenous life had degenerated into fatalistic lassitude is a myth", as shown by continued vitality in many areas, including literature and art for example. ${ }^{6}$

4 JW Davidson Samoa mo Samoa: the emergence of the Independent State of Western Samoa (Melbourne University Press, Melbourne, 1967). On Davidson, see Doug Munro The lvory Tower and Beyond: Participant Historians of the Pacific (Cambridge Scholars Publishing, Newcastle upon Tyne, 2009) at 77121. Munro's book is a portrait gallery of a number of prominent Pacific historians, including Davidson, J C Beaglehole, Richard Gilson and Harry Maude.

5 On this historiographical debate see for example JW Davidson "Problems of Pacific History: Past, Present, and Future" (1966) 1 The Journal of Pacific History 5-21; KR Howe "The Fate of the Savage in Pacific Historiography" (1977) 11 Journal of New Zealand History 137; Paul Monin "The Challenge of Writing Race-Interaction History in the Era of Maori Resurgence and the Waitangi Tribunal" (2002) Journal of New Zealand Literature 79; RP Boast Buying the Land, Selling the Land: Governments and Maori Land in the North Island 1865-1921 (Victoria University Press, Wellington, 2008) at 14-17. In my view there is sometimes a risk of carrying a reaction to so-called 'fatal impact' history too far. For a similar view see Richard Hill Maori and the State: Crown-Maori Relations in New Zealand/Aotearoa 1950-2000 (Victoria University Press, Wellington, 2009) at 5-6.

6 Nicholas Thomas Possessions: Indigenous Art/Colonial Culture (Thames \& Hudson, London, 1999) at 46. See also Nicholas Thomas Islanders: the Pacific in the Age of Empire (Yale University Press, New Haven and London, 2010) at 2-5. Here, Thomas makes the important point that it is one thing to decide to move away from fatal impact history, but quite another to decide how to do that practically at 3 :

[t]he propensity of recent scholarship, which affirms cultural continuities and native resilience, certainly makes Islanders active rather than passive, but reinforces the old notion that Islanders are in situ, they inhabit particular places, they are the 'local' opponents, translators, or recipients of 'global' forces, meanings and commodities, emanating largely from the West

In this book, Thomas explores the extent to which empire in the Pacific was more than "the establishment of disestablishment of presumptuous forms of government"; it was "conspicuously violent, yet replete with possibilities, marked out by travels, possible travels, and travels of the mind" (ibid, at 297). Thomas sees the colonial period as one which opened new doors and new possibilities for indigenous peoples in the Pacific, 
Yet when it comes specifically to legal history the fatal impact school is clearly alive and well, even amongst historians who are themselves pioneers of new approaches to the study of the colonial encounter. Few historians want to be perceived as fatal impact historians today, the term carrying negative implications of naivety, lack of nuance, insufficient sensitivity to indigenous resilience and continuity, and even Eurocentrism. Nevertheless, descriptions of an institution such as the Native Land Court in New Zealand can sometimes be as fatal impact as it gets. To Judith Binney, for instance, the Court was known to Māori as the land taking court and she has described the Native Lands Act 1865 as an "act of war". 7 Binney cannot even remotely be described as subscribing to a fatal impact vision of Māori history: her books, on the contrary, are highly nuanced and multifaceted explorations of indigenous creativity and resilience. ${ }^{8}$ To take another example, in a recent scholarly general history of New Zealand Philippa Mein Smith has described the Land Court as "worse" than confiscation of land under the New Zealand Settlements Acts, and states also that the Native Land Court "certainly earned its contemporary title of the 'land-taking court"'. ${ }^{9}$ Moreover to some extent fatal impact history has undergone a new lease of life and renewed vitality in New Zealand as a result of the work of the Waitangi Tribunal, set up in 1975 and which has now released over 100 reports. ${ }^{10}$ Historians seem to be very resistant to the notion that Māori people might well have had their own reasons for bringing cases before the Court, might have been using the Court for their own purposes, and might indeed have impacted on the Court just as much as it impacted on them. To say this is not to claim that Māori liked the Court much, or that they would not have vastly preferred some other process, but given that they had to live with the Native Land Court it seems that the extent to which Māori were able to manage and manipulate its processes is at least a valid issue for discussion.

a rather different emphasis from that of the Lockhart school discussed in this article, which tends to bring to the fore indigenous conservativism and resilience. Both perspectives no doubt have their own validity.

7 J Binney "The Native Land Court and the Maori Communities" in J Binney, J Bassett and E Olssen (eds) The People and the Land: Te Tangata me Te Whenua: An lllustrated History of New Zealand 1820-1920 (Allen \& Unwin, Wellington, 1990) 143. There are many parallels between the tenurial changes that took place in New Zealand and processes elsewhere in the Pacific, for example in Hawai'i. For a range of perspectives on tenurial change in Hawai'i see Lilikalā Kame'eleihiwa Native Land and Foreign Desires: Pehea Lā E Pono Ai? (Bishop Museum Press, Honolulu, 1992); Jonathan Kay Kamakawiwo'ole Osorio Dismembering Lāhui: A History of the Hawaiian Nation to 1887 (University of Hawai'i Press, Honolulu, 2002); Robert H Stauffer Kahana: How the Land Was Lost (University of Hawai'i Press, Honolulu, 2004); Jon M Van Dyke Who Owns the Crown Lands of Hawai'i? (University of Hawai'i Press, Honolulu, 2008).

8 See Judith Binney Encircled Lands: Te Urewera, 1820-1921 (Bridget Williams Books, Wellington, 2009). Yet the "encircling" of which Binney writes was that of the Native Land Court.

9 Mein Smith A Concise History of New Zealand (Cambridge University Press, Cambridge, 2005) at 72-73.

10 The Tribunal is established under the Treaty of Waitangi Act 1975. On Waitangi Tribunal historiography there are two key works (both very different): Giselle Byrnes The Waitangi Tribunal and New Zealand History (Oxford University Press, Melbourne, 2004); Michael Belgrave Historical Frictions: Maori Claims and Invented Histories (Auckland University Press, Auckland, 2005). 
The interaction between the law and 19th century Māori in any event covers a vastly bigger field of human endeavour and activity than, say, merely the criminal law or the official legal system's rules relating to land tenure. The law relating to succession is one illustration. To what extent, for example, did 19th century Māori people - or Tahitians, or Hawaiians - use wills? Were these wills written in the indigenous languages, and what did they stipulate? What insights might a study of wills written in Māori, Tahitian or Hawaiian yield? Or to take a different kind of example, to what extent did Māori or Hawaiian people have recourse to lawyers? How often did they consult lawyers, and about what kinds of matters? Did Māori people, for instance, use lawyers to draw up wills, contracts, and for the purposes of suing others, Māori and non-Māori, in the ordinary courts? To the possible rejoinder that these are questions of no real importance or interest, why should that be? Why should succession - something that affects everyone - be less interesting than the Great Mahele or the Treaty of Waitangi? To say so perhaps reflects nothing more than an institutional and fatal impact distortion of perspective.

One begins to long for an escape route or a number of escape routes. The contextual study of legal discourses as pioneered by J G A Pocock certainly is one, one which, very appropriately, has sunk deep roots in the South Pacific, and which is already proving fruitful with the work of PG McHugh, Mark Hickford and others. ${ }^{11}$ It is the main thesis of this short article that another escape route might exist, albeit one little noticed in Pacific historiography to date, at least as far as I can tell. The escape route lies in the work a school of Latin American ethnohistorians, known variously as the "Lockhart school" or the "New Philology". This group of scholars includes James Lockhart himself ${ }^{12}$ as well as Sarah Cline, ${ }^{13}$ Rebecca Horn, ${ }^{14}$ Matthew Restall, ${ }^{15}$ and Kevin Terraciano. ${ }^{16}$

11 See for example JGA Pocock "Law, sovereignty and history in a divided culture: The case of New Zealand and the Treaty of Waitangi" (1998) 43 McGill LJ 481; Paul McHugh Aboriginal Societies and the Common Law: A History of Sovereignty, Status and Self-Determination (Oxford University Press, Oxford, 2004); Mark Hickford "'Decidedly the Most Interesting Savages on the Globe': An Approach to the Intellectual History of Maori Property Rights, 1837-1853" (2006) 27 History of Political Thought 122; Mark Hickford "Strands from the Afterlife of Confiscation: Property Rights, Constitutional Histories and the Political Incorporation of Maori, 1920s" in RP Boast and RS Hill (eds) Raupatu: The Confiscation of Maori Land (Victoria University Press, Wellington, 2009) 169.

12 See especially James Lockhart The Nahuas After the Conquest: A Social and Cultural History of the Indians of Central Mexico, Sixteenth Through Eighteenth Centuries (Stanford University Press, Stanford, 1992) [Nahuas]; James Lockhart "Sightings: Initial Nahua Reactions to Spanish Culture" in Stuart B Schwartz (ed) Implicit Understandings: Observing, Reporting and Reflecting on the Encounters between Europeans and Other Peoples in the Early Modern Era (Cambridge University Press, Cambridge and New York, 1994) 218; James Lockhart Of Things of the Indies: Essays Old and New in Early Latin American History (Stanford University Press, Stanford, 1999) [Of Things of the Indies]. Perhaps the Lockhart or New Philology school could also be called the "Stanford" school as most of their writings appear under the prestigious imprint of Stanford University Press.

13 See Sarah L Cline Colonial Culhuacan 1580-1600: A Social History of an Aztec Town (University of New Mexico Press, Albuquerque, 1986); Sarah L Cline "The Spiritual Conquest Reexamined: Baptism and Christian Marriage in Early Sixteenth-Century Mexico" (1993) 73 The Hispanic American Historical 
The new philologists are not concerned with law as such, but what is interesting about their work to the legal historian is their concentration on legal documents; wills, petitions, contracts, notarial acts and so forth. Working from this material, Lockhart and his disciples have created a new kind of history of indigenous encounters. ${ }^{17}$ Judiciously applied, the style of history practised by the new philologists could yield some new and fruitful insights for Pacific legal history, and this is the main argument of this article.

\section{SOURCE MATERIALS}

The practitioners of the new philology, which will be analysed further below, are a group of ethnohistorians based primarily in the United States who write mainly about Mexico. The focus on Mexico is easy to explain: the new philologists are interested in colonial-era documents written in indigenous languages, and these Mexico provides in abundance. (So, too, does New Zealand, a point which will be dwelt on later.) Pre-Columbian Mexico had a number of ancient writing traditions and produced books and written inscriptions of various kinds, and it seems that Mesoamerican indigenous people took readily to writing in indigenous languages but using Latin script following the Spanish conquest. Large quantities of wills, contracts, and notarised documents of various kinds exist, written in such languages as Maya, Nahuatl, and Mixtec. It is precisely documents of this kind that the new philologists are interested in. The other obvious Latin American region that might interest historians of these leanings is the Andes, especially the Peruvian and Bolivian Andean regions, but in fact it appears that the volume of indigenous documents available for study in these

Review 453; Sarah L Cline "Native Peoples of Colonial Central Mexico" in Richard EW Adams and Murdo J Macleod (eds) The Cambridge History of the Native Peoples of the Americas (Cambridge University Press, Cambridge, 2000) 287.

14 Rebecca Horn Postconquest Coyoacan: Nahua-Spanish Relations in Central Mexico, 1519-1650 (Stanford University Press, Stanford, 1997).

15 Matthew Restall The Maya World: Yucatec Culture ond Society, 1550-1850 (Stanford University Press, Stanford, 1997) [Maya World]; Matthew Restall Maya Conquistador (Beacon Press, Boston, 1998); Matthew Restall Seven Myths of the Spanish Conquest (Oxford University Press, New York, 2003).

16 Kevin Terraciano The Mixtecs of Colonial Oaxaca: Nudzahui History, Sixteenth through Eighteenth Centuries (Stanford University Press, Stanford, 2001) [Mixtecs].

17 Useful historiographical discussions include Stephen Haber "Anything Goes: Mexico's 'New' Cultural History" (1999) 79 Hispanic American Historical Review 307; John E Kicza "Recent books on Ethnohistory and Ethnic Relations in Colonial Mexico" (1995) 30 Latin American Research Review 239; John E Kicza "New Interpretations of Colonial Mexico from the Conquest to Independence" (2005) 40 Latin American Research Review 326; Cynthia Radding "Cultural Dialogues: Recent Trends in Mesoamerican Ethnohistory" (1998) 33 Latin American Research Review 193; Matthew Restall "A History of the New Philology and the New Philology in History" (2003) 38 Latin American Research Review 113; Susan Migden Socolow "Putting the 'Cult' in Culture" (1999) 79 Hispanic American Historical Review 355; Eric Van Young "The New Cultural History comes to Old Mexico" (1999) 79 Hispanic American Historical Review 211. 
zones is much less, perhaps explained by the absence of a pre-European tradition of writing inscriptions and manuscripts.

In this article I will focus on three major books, each of them dealing with the fate of a Mesoamerican people under Spanish rule. The three books are James Lockhart's The Nahuas After the Conquest, (1992), ${ }^{18}$ Matthew Restall's The Maya World: Yucatec Culture and Society 15501850 (1997) ${ }^{19}$ and Kevin Terraciano's The Mixtecs of Colonial Oaxaca (2001). ${ }^{20}$ These books build on earlier studies of colonial interaction by scholars such as Charles Gibson and Nancy Farriss. ${ }^{21}$ Each book is about the history of an indigenous group during the colonial period. Each group, the Nahuas, Mayas and Mixtecs, belonged to a great pre-Columbian indigenous civilization characterised, amongst other achievements, by a long tradition of glyphic writing and the production of inscriptions and painted manuscripts and books. ${ }^{22}$ Each culture also learned from the Spanish friars how to write their own languages using Latin script, resulting in the creation of a large body of written material during the colonial period. I do not intend to analyse each of these rich and complicated works in full, but will focus on two issues only, these being the kinds of source material that Lockhart and his colleagues are interested in, and secondly the types of questions that they ask of it.

James Lockhart, who has written about both Peru and Mesoamerica as it happens, is the doyen of the new philology. He is the author of the leading text in the field (The Nahuas After the Conquest) and also of many articles and papers, including an interesting intellectual autobiography published in $1999 .^{23}$ The Nahuas, the subject of his pioneering 1992 monograph, are an indigenous

18 Lockhart Nahuas, above n 12.

19 Restall Maya World, above n 15.

20 Tarraciano Mixtecs, above n 16.

21 Charles Gibson The Aztecs under Spanish Rule (Stanford University Press, Stanford, California, 1964); Nancy M Farriss Maya Society under Colonial Rule (Princeton University Press, Princeton, 1984). These earlier works are more orthodox treatments of colonial interactions, based mainly on Spanish-language documents. Both these books are more accessible in some ways than the works of the new philologists and do not seem to me to have been in any sense displaced. The new philology is certainly very distinctive and interesting, but whether it conveys the reality of the colonial encounter more reliably than the earlier works of Gibson and Farriss is an open question.

22 These three groups are defined primarily by language. Lockhart is writing about the Nahuatl-speaking peoples, who included those belonging the pre-Columbian indigenous state that we refer to as to as the Aztecs, but also included people who, while Nahuatl-speaking, were in fact politically opposed to the Aztecs of Tenochtitlan, the people of Tlaxcala being one example. Similarly, Restall is writing about the Yucatec Maya people, who were never politically unified before the colonial period. Yucatec, still widely spoken in the northern Yucatan today, is but one of a number of languages belonging to the Maya family: other important Maya languages include the K'iche language of the Guatemalan highlands, and the Tzeltal and Tzotzil languages of Chiapas. These languages also have long traditions of literature and writing.

23 Lockhart $O f$ Things of the Indies, above n 12, at 333-367. 
people based mainly in Central Mexico. They form a large socio-linguistic grouping that remains of great importance today and whose ancestors established and developed some of the great classical civilizations of ancient Mexico, including the groups referred to today as the Toltecs and Aztecs. (Some scholars believe that the more ancient Teotihuacan civilization was also Nahua.) Nahuas are those people who speak the Nahuatl language. Nahuatl has been a written language for a millennium, if not longer, written before the Spanish conquest in glyphs and since then in Latin script, sometimes interposed with glyphs in some texts. The language has a rich literature, continues to be studied and taught in Mexico, is spoken by over one million people, and continues to have poetry and other literature written in it. In the first paragraph of this remarkable book Lockhart emphasises that the people he is writing about are defined above all by language: the Nahuas "at the time of European contact were united, to the extent that they were, not by politics or even by an assertive consciousness of unity, but by a shared culture carried in the vocabulary of their common language". ${ }^{24}$ Language is the keynote from the beginning.

Lockhart explains that the purpose of The Nahuas after the Conquest "is to throw light on the history of Nahua society and culture through the use of records in Nahuatl" during the colonial period. ${ }^{25}$ Lockhart goes on to describe how this corpus of written documentation arose: ${ }^{26}$

The Franciscans, other ecclesiastics, and possibly some literate Spanish laymen taught enough Nahuas how to write their own language in the Roman alphabet that the art became self-perpetuating among writing specialists throughout the Nahua world, serving as the normal medium for record-keeping of all kinds. The practice continued for generation after generation for most of the time up to Mexican independence, creating a large and varied corpus with remarkable time depth and uninterrupted continuity. Much of the material once preserved in local centers across the central Mexican countryside - indeed, apparently most of it - has been lost, but a great deal reached Mexico City through litigation and is still to be found in various sections of Mexican national archive, not to speak of special caches in repositories in Mexico, [the United States], and elsewhere.

As can be seen, Lockhart is interested in litigation records not because he wishes to study legal processes, but rather because litigation files happen to preserve colonial-era documents written in indigenous languages. Lockhart is concerned, moreover, with a particular type of indigenous document - not the well-studied great chronicles and texts written in Nahuatl such as Sahagún's Florentine Codex, but rather with mundane documents such as letters, petitions and wills. Lockhart's

24 Ibid, at 1. Arguably the same is true of Tahitians, Hawaiians and Māori at the time of European contact. Modern Māori history can be seen as a continuous tension between local particularism, which still remains important, and attempts to build pan- Māori political organisations, including the King movement and the various parliamentary movements of the 19th century, the Rātana movement, the Māori Council and the Māori Congress in the 20th century, and the Māori parliamentary party in the 21 st.

25 Lockhart Nahuas, above n 12, at 1.

26 Ibid, at 6 
focus is not simply on indigenous-language documents but more specifically on day-to-day ordinary indigenous documents. The style of scholarship practised by Lockhart and his colleagues is quite unlike that practised by Rolena Adorno and others who focus on major chronicles, literary works and histories written in Nahuatl, Maya or Quechua. ${ }^{27}$ (A New Zealand equivalent of the latter might be Tamihana Te Rauparaha's lengthy Māori-language history of his famous father, the Ngāti Toa chief Te Rauparaha, which still has never been published in a modern critical edition and translated.) Nor does the work of the Lockhart school have much in common with the work of those who are interested in exploring the continuity of indigenous literary and scholarly traditions from pre-European times down to the present. ${ }^{28}$ Furthermore Lockhart is concerned strictly with the colonial period, and is not concerned with using indigenous-language documents to reconstruct preconquest political entities and political history, this being a thriving field in its own right. ${ }^{29}$

In Nahuas After the Conquest Lockhart explains his particular mission further: ${ }^{30}$

By the 1970s, scholars in both Mexico and this country were finally ready to turn to the more mundane documentation in Nahuatl. Some of it had been catalogued for decades, so the mere fact of its existence was not, properly speaking, a surprise. But the extent, richness and variety of the corpus surprised and continued to surprise those involved in opening it up. Done by Nahuas for Nahua eyes and for the purposes of everyday life, these documents, though most of them are ostensibly in Spanish genres, are not only more individual in their language, conventions, and content than their Spanish counterparts, but more complex in belonging to two traditions rather than one. They are both more difficult and potentially richer (that is, per item) than Spanish records. A realization of their nature has called forth a New Philology to render them understandable and available and put them in their true context. In the

27 Rolena Adorno has written extensively on an extraordinary manuscript written partly in Quechua and partly in Castilian by Felipe Guaman Poma de Ayala (1536-1616), a monumental illustrated work known as El primer nueva corónica y buen gobierno [The First New Chronicle and Good Government]. See for example Rolena Adorno Cronista y príncipe: La obra de Don Felipe Guaman Poma de Ayala (Pontficia Universidad Católica del Perú, Lima, 1989); Rolena Adorno The Polemics of Possession in Spanish American Narrative (Yale University Press, New Haven and London, 2007).

28 Distinguished examples of this approach include Miguel León-Portilla Literaturas Indígenas de México (Editorial Mapfre, Fondo de Cultura Económica Madrid, México DF, 1992); Dennis Tedlock 2000 Years of Mayan Literature (University of California Press, Berkeley and Los Angeles, 2010). There is a small industry focusing on indigenous chronicles, maps, and painted pictorial histories: see for example Elizabeth Hill Boone Stories in Red Black: Pictorial Histories of the Aztecs and Mixtecs (University of Texas Press, Austin, 2000); Dana Leibsohn Script and Glyph: Pre-Hispanic History, Colonial Bookmaking, and the Historia Tolteca-Chichimeca (Dumbarton Oaks Research Library and Collection and Harvard University Press, Washington DC, 2009).

29 See for example Pedro Carrasco Estructura politico-territorial del Imperio tenochca: La Triple Alianza de Tenochtitlan, Tetzcoco y Tlacopan (Colegio de México Fideicomiso Historia de las Américas y Fondo de Cultura Económica, México DF, 1996).This is a comprehensive study of the political structure of the 'Aztec' state base principally on Nahuatl manuscripts.

30 Lockhart Nahuas, above n 12, at 7. 
wake of the philological activity, often inextricably bound up with it or indistinguishable from it, have come dissertations, articles, and monographs using the new sources for substantive analysis of aspects of Nahua social or cultural history. The present work is one of these.

Kevin Terraciano, who has focused on the Mixtec people of Oaxaca, similarly stresses the importance of ordinary, day-to-day, documents written in native languages. As with Lockhart, the textual and linguistic nature of the enterprise is emphasised from the beginning: "This history is based primarily on Nudzahui [Mixtec] writings from the period, including pictorial texts and nativelanguage alphabetic records". ${ }^{31}$ Like Lockhart Terraciano uses the term "new philology" to describe his own approach and that of his scholarly confrères: $:^{32}$

The development of a historical approach based on native-language sources, called the "New Philology" by Lockhart and some of his colleagues, proceeds from social history in its concern with the behaviour of groups and individuals. It also represents a shift of emphasis from institutional and career pattern history to the study of culture, modes of organization, and ways of thinking embedded in native concepts and terminology.

What precisely are these "mundane" documents? Terraciano provides a helpful checklist: ${ }^{33}$

More than twenty types of archival documents are written entirely in the Mixtec language, including last wills and testaments (of nobles and commoners, men and women), inventories, personal letters, criminal records (reports, testimony, confessions), land transactions (transfers, sales, and lease agreements), sales of houses and businesses, personal business accounts and inventories, community fiscal accounts, election results, tribute records, petitions to Spanish authorities, official decrees, ecclesiastical records (marriages and baptisms), primordial titles or "false titles," and the proceedings of local cqbildos (municipal councils) on internal civil matters.

Restall identifies the main categories of mundane documents as testaments, land transaction records, other types of sales, petitions, election records, criminal records, community budget records, tribute records, census records, records relating to church business and "cofradías", ${ }^{34}$ "church-sponsored texts", and "ratifications of Spanish records". ${ }^{35} \mathrm{He}$ estimates that there are "tens of thousands" of such documents written in Nahuatl, about two thousand in Yucatec Maya, and

31 Terraciano Mixtecs, above n 16, at 1.

32 Ibid, at 7.

33 Ibid, at 9 .

34 A "cofradía" is a characteristic institution of Iberian and Latin American Christianity, essentially a lay brotherhood, often organised by trade or profession, which takes responsibility for certain aspects of Church management and for participation in religious festivals, and which also have charitable purposes.

35 Matthew Restall "Heirs to the Hieroglyphs: Indigenous Writing in Colonial Mesoamerica" (1997) 54 The Americas 239 at 243. 
about five hundred in Mixtec. ${ }^{36}$ As will be shown later in this article, similar documents written in Māori can readily be found in 19th century New Zealand. My guess is that the number of documents in 19th century Māori would easily equal and probably surpass the corpus available in Nahuatl. New philologists also like to supplement their "mundane" documents with colonial-era dictionaries and grammars of Native languages compiled by missionaries, which certainly exist in New Zealand as well.

Many of these documents were generated in the course of legal proceedings. Litigation between indigenous communities in colonial courts was routine in colonial Mexico. A dispute about a will or about the land rights of a particular town would inevitably lead to indigenous-language documents appearing on the court files. In Oaxaca "[m]ost of the surviving sources were used as evidence in local civil and criminal disputes adjudicated by the Spanish alcalde mayor in a given administrative and legal jurisdiction, or alcaldía mayor". ${ }^{37}$ As seen, Lockhart points out that while most of the indigenous mundane documentation has been lost, a substantial amount has survived through litigation and thus can still be found on case files in the archives in Mexico City. ${ }^{38}$ Restall also notes the pivotal importance of legal records: "the colonial period saw the production of an extensive body of documentation - overwhelmingly notarial and largely legal in nature". ${ }^{39}$ Another type of document much beloved of the new philologist is the testament, self-evidently legal documents given that Spanish colonial law required them to be notarised, and there are now a number of monographs dealing specifically with indigenous-language wills from various parts of Mexico. ${ }^{40}$ (How often Māori made wills in the 19th century is unknown.) Petitions are another important category of document, "often rich in a reverential language that evokes pre-conquest precedent and indigenous style". 41

\section{INTERROGATING THE EVIDENCE}

It can be seen then that one aspect of the distinctiveness of the new philology is the emphasis placed by its practitioners on a particular, and hitherto unexploited, category of source materials legal and notarial "mundane" documents in the native languages. Even more important than the

6 Ibid.

37 Terraciano Mixtecs, above n 16, at 9.

38 Lockhart Nahuas, above n 12, at 7.

39 Restall "Heirs to the Hieroglyphs", above n 35, at 240.

40 Sarah Cline and Miguel Leon-Portilla (eds) The Testaments of Culhuacan (UCLA Latin America Center Publications, University of California, Los Angeles, 1984); Susan Kellogg and Matthew Restall (eds) Dead Giveaways: Indigenous Testaments of Colonial Mesoamerica and the Andes (University of Utah Press, Salt Lake City, 1998); Caterina Pizzigoni Testaments of Toluca (Stanford University Press, California, 2006).

41 Restall "Heirs to the Hieroglyphs", above n 35, at 258. 
distinctive source materials are the kinds of questions the new philologists are interested in pursuing.

What are the books of Lockhart, Restall, Terraciano and others actually about? Readers who come to them hoping perhaps for a sequel to Hugh Thomas' vivid chronicles of the rise of the Spanish empire and the conquest of Mexico ${ }^{42}$ are likely to find The Nahuas After the Conquest or The Maya World somewhat technical, surprisingly focused on technicalities of grammar and writing, and maybe a bit boring. Perhaps a glance at the tables of contents of the three main books discussed in this article will convey the style and approach of the new philologists most clearly. Lockhart's Nahuas After the Conquest has an introductory chapter followed by chapters on the altepetl (roughly speaking the indigenous city-state the basic political unit), the household, social differentiation, land and living, religious life, language, "ways of writing", and forms of expression. ${ }^{43}$ Restall's Maya World is divided into four sections, "identity and organization", "society and culture", "land and material culture", and "literacy and language", and has chapters on such subjects as "names", "class", "daily life", "gender", "land description", "tenure and exchange", "notarial purpose and style", "petitions", "election records", and "language". ${ }^{44}$ Terraciano's Mixtecs of Colonial Oaxaca, following an extensive introduction dealing with the historiography and evidence, has chapters on "writing", "language", "communities", "social relations", "yuhuitayu" (diplomatic or political marriages), "land and livelihood", "sacred relations", and "ethnicity". ${ }^{45}$

Essentially the books are all works of social and cultural history, trying to work within indigenous viewpoints and indigenous ways of categorising and describing their own social organisation. Lockhart and his colleagues are interested above all in what they call "categories of thought", how indigenous people understood and conceptualised the world in which they lived. For example, Restall points out that Maya people hardly ever used the term Maya to describe themselves, indicating that a sense of ethnic differentiation vis-à-vis Spaniards was not an important category of thought as far as they were concerned: "they clearly did not recognize that distinction as primary or even legitimate from their perspective". ${ }^{46}$ To take this a little further, while we are obsessed with ethnicity, people in the past simply may not have been. Local identities may have been far more important, or people may have actively tried to resist being differentiated by ethnicity. That is, while Spaniards in the Yucatan may have seen the Maya people as "Maya" or as "Indians", Maya people themselves resisted this and sought to emphasise instead local identities as well as

42 Hugh Thomas The Conquest of Mexico (Hutchinson, London, 1993); Hugh Thomas Rivers of Gold: The Rise of the Spanish Empire (Weidenfeld and Nicolson, London, 2003).

43 Lockhart Nahuas, above n 12, at vii-viii.

44 Restall Maya World, above n 15, at ix-x.

45 Terraciano Mixtecs, above n 16, at vii-viii.

46 Restall Maya World, above n 15, at 15. 
local alliances and connections with Spaniards or with the Spanish Crown and ecclesiastical organisations. My own impression is that this is equally true of most 19th century Māori people, to whom local iwi and hapu identities were always paramount and far more significant than being Māori as opposed to Pakeha, but this is something that needs to be explored systematically.

These aspirations to come to grips with categories of thought explain in part the careful attention paid to language, grammar, and writing. Lockhart argues that ideally the historian would like to track the lives of humble people in order to gain a full understanding of indigenous history in the colonial period. However the documentation is such that only rarely is it possible "to track a single person through a variety of documents": 47

Largely deprived of seeing the pattern in a succession of actions, we must fall back on the other aspect of the career-pattern approach, a close attention to the categories that the person and his peers used to classify himself and his thoughts and actions, as well as the phenomena surrounding him, thus studying concepts borne in a person's language rather than patterns manifested in the person's life. Only in the original language can the categories be detected for in a translation one sees the categories of the translator's language instead.

Terraciano explains the objectives of the new philology in similar terms: ${ }^{48}$

The advantage of using Ñudzahui-language sources for a history of Ñudzahui people requires little explanation. I am concerned with the categories that people used to describe themselves, other people, things, actions, ideas, and concepts. The language is crucial to understanding cultural categories. The original terminology is accessible only through the native language. Spanish translations avoided the use of native words. Fundamental indigenous categories and concepts are embedded in the language of each document, regardless of its specific content.

New philologists aspire to enter directly into the conceptual universe of the people they are writing about, based on a strict and rigorous concentration on mundane indigenous documents.

All three authors devote a great deal of time to exploring the nature of indigenous socio-political organisation as conceived by indigenous people themselves. They thus avoid the terminology of political history and anthropology and such terms as city state, tribe, clan, chief or whatever and instead focus on the ways in which indigenous people thought of their political units and subunits and the terminology that Nahuas, Mayas and Mixtecs ordinarily used. In all three cases the core unit was a typically Mesoamerican entity known respectively as the "altepetl" in Nahua, the "ñu" in Mixtec and the "cah" in Maya. As Terraciano puts it, "[t]he nuu was as central to local indigenous organisation as the altepetl in central Mexico and the cah in Yucatan". ${ }^{49}$ These terms roughly equate

47 Lockhart Nahuas, above n 12, at 7-8.

48 Terraciano Mixtecs, above n 16, at 8-9.

49 Ibid, at 103. 
to the indigenous ethnic city-state, more of a territorial unit than one based on kinship, which was itself divided into smaller subunits and which endlessly combined and recombined with others to form large polities equivalent to states. Lockhart defines "altepetl" as "ethnic state", or "an organization of people holding sway over a given territory". ${ }^{50}$ Sometimes, depending on the context, these words basically mean simply "place" - Mesoamericans were centred on places and localities in the same way that Polynesian peoples were centred on categories of descent. All three books devote a great deal of time to carefully exploring these complex indigenous polities and the indigenous terminology used to describe and analyse them. ${ }^{51}$

As well as this focus on indigenous categorisations of social and political organisation, another characteristic of all three books, and indeed of the new philology in general, is a fascination with language, documents and writing as subjects of historical inquiry in their own right. All three books devote long chapters to these subjects. Lockhart, for instance, has analysed carefully the steps by which the indigenous pictographic style of writing of the Nahuas gradually developed into fully fledged written documents in Nahua using Latin script. ${ }^{52}$ Over a quarter of Restall's book on the colonial Maya is concerned with writing and language. ${ }^{53}$ Terraciano similarly has a long and richly documented chapter on writing. He traces how Mixtec writing evolved during the colonial period, beginning with their own native "magnificent pictographic writing tradition" based on painted ideograms and images on bark paper. During the early colonial period Mixtec scribes began to combine pictographs drawn from the native manuscript tradition with words written in Mixtec using Latin script; this in turn developed into fully-fledged written Mixtec texts. ${ }^{54}$ This emphasis on writing and language is one of the most distinctive aspects of the work of Lockhart and his colleagues. In fact the new philologists can be open to the accusation of overdoing things somewhat in this respect. It would be interesting to poll readers to find out how many skipped over the long and often highly technical discussions of shifts in grammar, writing style, and vocabulary.

As important as what these books are about is what they are not about. That much contested institution, the Spanish "encomienda", the grant of a right to receive tribute or labour services, over which a vast amount of ink has been spilled over the years, is not much in evidence. ${ }^{55}$ The sub-text

50 Lockhart Nahuas, above n 12, at 14.

51 Ibid at 14-58; Restall Maya World, above n 15, at 13-40; Terraciano Mixtecs, above n 16, at 102-132.

52 Lockhart Nahuas, above n 12, at 326-373.

53 Restall Maya World, above n 15, at 229-304.

54 See Terraciano Mixtecs, above n 16, at 15-65.

55 An encomienda is a grant or allocation of a right to tribute and labour services. The classic study is Lesley Byrd Simpson The Encomienda in New Spain (University of California, Berkeley and Los Angeles, 1950); equally classic is François Chevalier La formación de los latifundios en México: Haciendas y sociedad en los siglos XVI, XVII y XVIII (Fondo de Cultura Económica, México DF, 1999) (originally published in 
is that the encomienda was simply not all that important when compared to the evidence of continuity and slow change that is perceived as the actual reality of colonial life. The debates over law and policy that took place in imperial Spain and in the upper reaches of the colonial administrations in Mexico and Peru, likewise a subject with a vast literature are completely ignored. ${ }^{56}$ The message that is conveyed, implicitly rather than explicitly, is that Vítoria's lectures and the books and polemics of Las Casas had no impact whatever at the local level of altepetl, nuu, and $c a h$ that the new philologists are writing about. Again, to translate this to a New Zealand context, it would be rather like writing a 500-page densely referenced book on 19th century Māori history without mentioning the Declaration of Independence of 1835 or the Treaty of Waitangi even once. Whether this would amount to a gain or a loss in historical understanding is a question worth pondering.

To the legal historian, books such as Lockhart's Nahuas After the Conquest are, for all their novelty and sophistication, somewhat unsettling and puzzling, arising out of a fundamental contradiction of approach: while the books are based on legal documents they are not at all about legal processes. Thus Lockhart, Restall and Terraciano rely very much on testaments as a source, but we learn nothing at all about the law relating to succession in colonial Mexico. The linguistic and textual context is addressed at length, but the legal not at all. The new philologists are fascinated by language and text, and dwell on both at length, but they are not interested in law, courts, or judicial processes except insofar as they serve to generate "mundane" documents in native languages. The legal framework of colonial and imperial ordinances and the structure and workings of courts and appeals is not traversed. What seems to be an obvious question, that is the relationship between indigenous customary law and the Spanish colonial law in such areas as land tenure, marriage and succession, is not explored in any systematic way. Thus while legal historians may find the use made of legal documents by these writers novel and very interesting, they will need to turn elsewhere to find answers to those questions that are of specific interest to them.

\section{APPLICATION TO NEW ZEALAND AND PACIFIC HISTORY}

It seems that a history of 19th century Māori using the techniques of the new philologists could at least be attempted. There are some strong similarities between the history of, say, the Nahua language in 16th century Mexico and the Māori language in 19th century New Zealand. In both cases, initially under missionary influence, Nahuas and Māori learned to write their own language in Latin script. This in turn became, as Lockhart has put it, "self-perpetuating": Māori taught writing to one another, and literacy in Māori soon became widespread, probably far more so than was the case

French as La Formation des grands domaines au Mexique: Terre et societé aux XVIe-XVIIe siècles (Institut d'Ethnologie, Paris, 1953).

56 The literature on this is too vast to be traversed in a footnote. For an introductory survey see RP Boast "The 'Spanish' Origins of International Human Rights Law: A Historiographical Survey" (2010) 41 VUWLR $235-272$. 
with Nahuatl or Maya in colonial Mexico. It is even possible that the Māori people were more literate in Māori than the Pakeha population was literate in English. Māori became active not only in reading and writing, but also in publishing pamphlets, books, and newspapers. Notwithstanding a tendency to characterise Māori culture, even today, as primarily oral, in fact the amount of 19th century written material in Māori is vast. ${ }^{57}$ Māori wrote letters to each other regularly and for Māori language newspapers ("niupepa") as well. ${ }^{58}$ These newspapers had their equivalents of the Letters to the Editor pages found in the English-language press, ("wharangi tuwhera", or "open page") and there are a considerable number of opinionated letters printed in them. Māori written scholarship emerged as well, and by the late 19th century Māori scholars were writing - in Māori - learned articles on traditional history and scholarship for publication in journals such as the Transactions of the New Zealand Institute or the Journal of the Polynesian Society. As well as works of scholarship there is also a very large written corpus of literary works. Mervyn McLean, a prominent ethnomusicologist, has written that it "is a surprise to nearly everyone, both Pakeha and Maori, to learn that literally thousands of Māori song texts have been preserved in written form, both published and unpublished". ${ }^{59}$ Māori could easily have evolved into a fully-fledged modern literary language today, and did not do so mainly because the New Zealand state embarked on an illconceived programme of discouraging its use. It is important to stress that the government's campaign against Māori was not a campaign against illiteracy, Māori people being already literate in Māori, but was a campaign against the language as such. When the Te Atiawa and Ngati Toa chief Wi Parata went to the missionary school at Otaki he was hoping to be taught how to read and write

57 An ideological fixation that Māori culture is 'oral' has probably contributed to the undervaluing and neglect of this astonishing written corpus. On Māori literacy and its significance see Tony Ballantyne Orientalism and Race: Aryanism in the British Empire (Palgrave Macmillan, London, 2002) at 146-158. Ballantyne takes issue with some earlier discussions of Māori literacy and writing by Judith Binney and DF McKenzie: see Judith Binney "Maori oral narratives, Pakeha written texts: Two forms of telling history" (1987) 21 Journal of New Zealand History 16-28; DF McKenzie Oral Culture, Literacy and Print in early New Zealand: The Treaty of Waitangi (Victoria University Press, Wellington, 1985). My own position is akin to Ballantyne's: see Boast, Buying the Land, Selling the Land, above n 5, at 11-12. If more people were made aware of the rich literary legacy in Māori perhaps more people would be interested in learning the language.

58 A new literature on Māori-language newspapers has begun to emerge: see Jenifer Curnow, Ngapare Hopa and Jane McRae (eds) Rere atu, taku mana! Discovering history, language and politics in the Maorilanguage newspapers (Auckland University Press, Auckland, 2002); Ngapare Hopa and Jane McRae He Pitopito Kōrero nō te Perehi Māori: Readings from the Maori-language Press (Auckland University Press, Auckland, 2006); Lachy Paterson Colonial Discourses: Niupepa Māori 1855-1863 (Otago University Press, Dunedin, 2006).

59 Mervyn McLean Tō Tātou Waka: In Search of Māori Music (Auckland University Press, Auckland, 2004) at 9 . 
and English and did not need to know how to read and write in Māori. He had already been taught how to do that by his mother. ${ }^{60}$

Just as in Mexico, there exists in New Zealand a wealth of "mundane" documentation of the kind that the new philologists are interested in. Nineteenth century letters in Māori abound in Māori Land Court correspondence files and in Native Land Purchase records. I have seen many of these letters myself in archival records, some of them scrawled out in haste, others carefully composed in a beautiful copperplate handwriting. Usually the letters are pinned to a translator's note, translating the Māori-language original into English for the benefit of officials and politicians who could not read Māori. I have no idea how many such documents there are, but to describe them as plentiful is an understatement. While Terraciano has had to make do with about 500 documents written in Mixtec, a historian embarking on a similar enterprise in New Zealand could easily have tens of thousands of documents to work with. Bradford Haami has pointed out that one effect of the Māori Land Court process was that it "stimulated a great volume of Māori writing - transcribed oral testimonies, letters, petitions - containing genealogies and histories that were used to prove rights to land". ${ }^{61}$ Government land purchasing policies had the same effect. How many petitions were sent to the government over land matters is anyone's guess, but there were certainly large numbers of them. Locating them would be arduous, as it would mean having to work through large numbers of mostly English-language files in order to locate and transcribe the "mundane" letters, petitions and so on written in Māori, but this is exactly the exercise that Lockhart and others have had to do in their search for Mixtec, Maya and Nahuatl documents, which tend to be buried amongst the Spanishlanguage documents.

The Māori Legal Archive, a recently completed digital collection made up of about 14,000 pages of text, has abundantly confirmed the existence of a very substantial corpus of Māorilanguage "mundane" legal documents. The Archive, hosted by the New Zealand Electronic Text Centre at Victoria University of Wellington, is the result of a joint project between the Library at Victoria University and the Legal Māori Project led by Māmari Stephens of the Faculty of Law at Victoria. ${ }^{62}$ The ultimate outcome of the Legal Māori Project will be the publication of a Māori Legal Dictionary, but the Māori Legal Archive, which is freely available for researchers, has already not only confirmed the sheer abundance of the available documents, including petitions and land

60 See evidence of Wi Parata to the Native Affairs Select Committee (14 July 1876), Le 1/1867/7. Wi Parata said he learned nothing of any value at the Otaki school. He said he could read and write in Māori but was taught to by his mother before he went to school. Most of the time the children at the school were engaged in "tilling the soil".

61 Bradford Haami Pūtea Whakairo: Maori and the Written Word, (Huia, Wellington, 2007) at 23.

62 On the Archive, see Jason Darwin and Māmari Stephens "The Legal Māori Archive: Construction of a Large Digital Collection" (2009) 51 New Zealand Library and Information Management Journal at 161171. 
deeds, but has demonstrated that the time is now ripe for the application of the methodology of the Lockhart school to Māori-language texts.

The contents of some of the leading works of the new philology were described above. One can appreciate how novel the application of this approach might be in the New Zealand context by imagining a book on 19th century Māori organised similarly. Instead of chapters on the Treaty of Waitangi, the New Zealand wars, the Native Land Court and land development schemes there could be a book with chapters on, say, "writing", "language", "communities", "sacred relations", "ethnicity", "land and livelihood" and "social relations". One can see very clearly that this would be a somewhat different and perhaps very rewarding and interesting approach to Māori history, one which places indigenous concepts at centre stage and which banishes such institutions as the Native Land Court to the periphery. Such a book would also focus on deep-seated continuities, and this is certainly the focus of the work of the new philologists. They do not claim that indigenous societies were unaffected and unmodified by the colonial encounter, but their books certainly do convey an impression of massive stability, continuity, and gradual change very much on the indigenous society's own terms. To Restall, Maya society and culture during the colonial period "remained far more complex and potent and had a greater capacity for localizing introduced concepts, than has previously been thought". ${ }^{63}$ Perhaps the same is true of Māori society.

The documentation thus is certainly there. It only awaits exploitation. Quite what such exploration might reveal remains to be seen.

\section{CONCLUSIONS}

What this article is suggesting is that the new philology need not be confined to Mesoamerica, but rather that it should work equally well provided that the basic prerequisite, a significant amount of mundane documentation written in an indigenous language, equally applies. New Zealand meets this prerequisite. Other Polynesian societies would also meet it, Hawai'i certainly, and probably Tonga, Samoa and Tahiti as well.

Of course compared with 16th and 17th century New Spain, 19th century New Zealand is much less remote than 16th century Mexico, and documentation of all kinds is abundant. Moreover a living oral tradition concerning 19th century events and traditional history still exists. ${ }^{64}$ It is much easier to track the fate of particular Māori individuals through the written records than is possible in colonial Mexico. New Zealand historiography is a rich and flourishing field, as shown by the nearcontinuous output of scholarly history books and biographies. Even so, historical writing of the kind pioneered and developed by Lockhart and others could still be very useful and illuminating, a valuable supplement to an already well-developed and variegated picture. As seen, Lockhart and his

63 Restall Maya World, above n 15, at 1.

64 See for example Binney, above n 57. 
colleagues are convinced of the special and unique value of the "mundane" sources because of their individuality and complexity, and it would be interesting to see what kinds of insights a similar exercise in New Zealand might yield.

One area where such an approach might prove helpful is in the area of the history of social organisation. As seen, Lockhart, Restall and Terraciano have been able to very effectively advance the understanding of Mesoamerican social organisation during the colonial period by moving the indigenous categories of altepetl, cah and $\tilde{n} u u$ to centre stage. They have also been well able to describe social change in the colonial period by analysing how these traditional categories interacted with the institutions of the colonial state. Maybe the changing roles of hapu and iwi could be better understood by means of a thorough analysis of the "mundane" Māori-language material on legal files than has been attempted to date. Such work would probably show the resilience, creativity and cultural stubbornness of Māori society, as has been shown to be the case for the colonial Nahuas and Mayas. It might be useful to move the Native Land Court and the government land purchaser off centre stage for once and to explore, instead, how Māori saw themselves as reflected in documents that they themselves wrote. 